\title{
Property price dependence from noise level on example of local real estate market
}

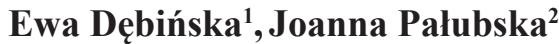 \\ ${ }^{1}$ Department of Integrated Geodesy and Cartography; Faculty of Mining Surveying \\ and Environmental Engineering; AGH University of Science and Technology in Krakow; \\ e-mail: ewa.debinska@agh.edu.pl ORCID:0000-0002-5152-8628 \\ ${ }^{2}$ Department of Integrated Geodesy and Cartography; Faculty of Mining Surveying \\ and Environmental Engineering; AGH University of Science and Technology in Krakow; \\ e-mail:palubska@agh.edu.pl,ORCID:0000-0001-8174-4156
}

\begin{abstract}
The research issues discussed concern the impact of the environmental factor on the level of real estate transaction prices. In the face of the dynamically developing road infrastructure but also the increase in the volume of car traffic, it is necessary to take into account the effects of these changes in the area of property appraisal. The noise level as part of the group of price-generating attributes should be taken into account as in many cases, and from the perspective of real estate buyers, it may prove to be the most important factor. The research was carried out on the example of housing properties located at the main communication artery of Krakow.
\end{abstract}

Keywords: road noise, prices of residential premises, environmental factors

\section{Introduction}

Socio-economic progress, especially in developed countries [1] is strongly correlated with infrastructure and innovation, where the road infrastructure has a positive impact on development, because effective investment activities in a given area require taking into account the existing and planned transport network. This interdependence, however, does not distinguish between the independent variable [2], because the processes of growth and development may occur with the existence of appropriate infrastructure, but also emerging investments in a given area force the creation of appropriate facilities and devices.

While the necessity of the existence and extension of the road network is an indisputable issue, the effects of these actions are the source of many consequences that each of us experiences to a greater or lesser extent. These consequences [1] may include: shortening travel time, reducing transport costs, improving its conditions and safety as well as socio-economic effects such as availability, employment, productivity, social exclusion and the natural environment.

In opposition to many positive aspects of the functioning of communication networks there are unfavourable factors, including environmental ones. The main ones are air pollution associated with the emission of harmful car exhausts and traffic noise, which is currently one of the most important civilization problems. Noise is classified as pollution of the natural envi- 
ronment and is defined as [3] sounds from 16 to $16,000 \mathrm{~Hz}$, which are undesirable and harmful [4], caused by human activity in the open air, including noise emitted by means of transport, road, rail, airplane traffic and noise originating from industrial areas. The term "unwanted sound" includes many factors: physiological, health and psychological, the scope of which will depend not only on the volume of noise pollution, but also on its intensity, frequency, duration, variability and time of occurrence during the day. The $19^{\text {th }}$ century [5] doctor Robert Koch already pointed out the danger of this phenomenon, warning that a day will come when man will have to fight a very dangerous enemy of his health - noise - the same way he once fought cholera and plague.

Society in Poland does not yet have a sufficiently high awareness of the scale of threats resulting from the impact of noise on their health and quality of life, as well as state agencies do not take sufficiently effective steps to counteract this phenomenon. The most susceptible to traffic noise are residents of large urban agglomerations, especially those living along the main thoroughfares, which are exposed to sleep, rest and work disturbances, neurosis, hearing impairment or cardiovascular disease risk.

The concept of noise correlates with other factors [6] such as the unpleasant smell of fumes, vibrations or air pollution. If the subject of the analysis is real estate, one should also take into account an unfavourable view or presence of artificial lighting on buildings along the most frequented roads. The tests carried out most often take into account the above elements in the form of one factor - traffic noise.

One of the parameters describing the noise level is the relative sound pressure level expressed in the logarithmic decibel scale $(\mathrm{dB})$. A summary of reactions to exemplary sound levels is depicted in Table 1 [7].

Table 1. An example of a reaction to sound at different frequency levels

\begin{tabular}{|c|c|c|c|}
\hline $\mathrm{dB}$ & Rating & The source being the sound source & Effects \\
\hline 140 & & gunshots, explosions & audio trauma \\
\hline 130 & & starting jet & \\
\hline 120 & & & pain above this threshold \\
\hline 110 & & pneumatic drill & \\
\hline 100 & & disco & \\
\hline 90 & & truck noise & \\
\hline 80 & & busy street, horn & interference in work \\
\hline 75 & very bad & & \\
\hline 70 & bad & car interior & interference in speech \\
\hline 65 & moderately bad & & \\
\hline 60 & moderate & window by busy street & \\
\hline 55 & tolerable & & \\
\hline 50 & average & silent street & normal \\
\hline 45 & good & & \\
\hline 40 & perfect & $\begin{array}{l}\text { quiet office, tearing a sheet of paper, the } \\
\text { sound of waves }\end{array}$ & sleep disturbance \\
\hline 30 & & library & \\
\hline 20 & & whisper & a sense of silence \\
\hline 10 & & desert & \\
\hline 0 & & & hearing threshold \\
\hline
\end{tabular}


In addition to the above-mentioned effects of traffic noise impact on our health, one should also pay attention to its significant impact on the level of obtained prices when selling residential properties located in large cities. The analysis of real estate considered in terms of a legal, technical object, a commodity which is the subject of market turnover and, above all, the investment objective [8] requires the adoption of an appropriate catalogue of features having the greatest impact on its value. In addition to economic, legal, demographic and political factors that particularly affect real estate, physical and environmental conditions also stand out. They are closely related to the location of the property and its liquidity. The permanence of the property in place means that it is susceptible to the environment, including its adverse influence of sources generating a high level of sound, in the case of a location near a busy road. The noise level associated with a given location of the real estate is more and more often considered as one of the attributes that significantly affects the value of the property and the negotiated transaction price in the event of its sale. In the face of the development of the communication network, but above all the increase in the number of road users, this feature may sometimes be as high as the location of the property.

\section{Review of the literature}

There are many studies on the impact of noise on the value and prices of real estate, including different sources of sound emissions and the adoption of various research methods [9] [10]. Most of this type of publication concerns foreign markets, and the submitted conclusions confirm the need to include this environmental factor in real estate market analysis.

It should be taken into account that the preferences of real estate buyers are very diverse and although the majority value peace and quiet, a large group chooses a flat near a busy and loud road but with better access to social infrastructure. In the case of large cities, such a choice is not always applicable, because the noise level for two units located in the same building but from different sides implies different levels of the incoming traffic noise.

The studies often use the NSDI (noise sensitivity depreciation index) [11], [12] expressing the percentage decrease in the value of real estate per $1 \mathrm{~dB}$ increase in noise, enabling comparison of the results obtained for specific real estate markets. At the same time, it should be noted that only sounds of appropriate frequency are taken into account in the research as a negative environmental factor. One of the tasks is to adopt an appropriate threshold value, beyond which the sound is perceived as unpleasant and undesirable. In the literature on the subject [13] it is indicated that the threshold value is $50 \mathrm{~dB}-55 \mathrm{~dB}$ [14] during the day, i.e. the level of sounds below which they are ignored by us and do not disturb our work, rest or performing various duties. Above this value, the sound becomes an element that negatively affects our perception of a given place.

Noise in Europe is characterized by an upward trend and the main factors of exposure to noise in the environment are: urbanization, growing demand for motorized transport and ineffective urban planning [15]. The increasing noise is affected by the poor quality of the surface and the lack of bypasses around cities where the roads are not adapted to accept heavy traffic. Both on the basis of Polish and European law, there are legal norms addressing the problem of traffic noise, where in Poland the existing regulations indicate acceptable levels of noise, depending on the type of terrain, sources of noise and time of day. The permissible noise level [16] resulting from road transport for residential areas of multifamily housing is Ldwn $=60 \mathrm{~dB}$, where Ldwn is the long-term average sound level A expressed in decibels $(\mathrm{dB})$, determined over all days of the year. 
The results of the conducted surveys indicate a drop in property prices by $0.08-2.22 \%$ with an average of $0.64 \%$ (Bateman et al., 2001), 0.21-0.61\% [14], 0.3-0.5\% [7] per $1 \mathrm{~dB}$ increase in sound. With regard to the average level of decline in property prices in the USA and Canada [10], the NSDI ratio is at $0.4 \%$. In the case of residential premises in Szczecin, the results indicate a decrease of $4 \%$ with an increase in the noise level by $5 \mathrm{~dB}$ [17]. The type of the analysed market is also significant, where the values of NSDI indices in the case of homes are at the level of $0.54 \%$ and residential premises of $0.47 \%$ [13]. At the same time [18], the problem of the lack of knowledge by buyers about the unfavourable attributes of a given real estate is pointed out, where sellers intentionally do not inform potential buyers about the nuisance noise associated with a given property, often placing the buyer in their own former position of being deprived of such information. Research conducted in Sweden on a single-family housing area indicates that noise increase by $1 \mathrm{~dB}$ level causes a $0.6 \%$ drop in the price of real estate. In general, sales prices of this type of real estate are about $30 \%$ higher in quiet areas compared to areas exposed to environmental factors, including the effects of the road impact such as accessibility, noise pollution and visual and aesthetic effects. Other studies [7] indicate that real estate prices in areas where noise level exceeds $65 \mathrm{~dB}$ are lower by up to $12 \%$, yet noise in the range of 41 to $65 \mathrm{~dB}$ has no significant impact on prices, while quiet areas (below $40 \mathrm{~dB}$ ) are characterized by a price premium of $6 \%$.

\section{Subject of study}

The scope of the research covered separate apartments located in the centre of Kraków:

- along one of the main communication arteries of the city, characterized by very large car traffic and noise level of $75 \mathrm{~dB}$ - Al. Three Tents,

- on side roads from Aleja Trzech Wieszczy, with varying degrees of traffic, in areas with noise levels of 50 to $70 \mathrm{~dB}$.

The gathered database includes transactions executed from the beginning of 2017 in the Krowodrza and Śródmieście districts, in the registration areas directly adjacent to Aleja Trzech Wieszczy, which also constitutes a border between the two described districts. The set created includes information about 200 residential premises, under the influence of noise at various levels of frequency (Table 2).

Table 2. Table for the number of residential premises in individual noise classes

\begin{tabular}{lll}
\hline Noise level & Krowodrza & Śródmieście \\
\hline $50-55$ & 8 & 13 \\
\hline $55-60$ & 17 & 21 \\
\hline $60-65$ & 13 & 39 \\
\hline $65-70$ & 14 & 27 \\
\hline $70-75$ & 11 & 13 \\
\hline
\end{tabular}

The acquired real estate is located in an area with a radius of about $1 \mathrm{~km}$ and should be considered in the first place in terms of the attractiveness of its location. In addition to the factor which is the location, the premises vary in the level of technical condition, the size of the usable area, the location on the floor and the noise level. Data analysis indicates a significant share of the technical condition of the building and the standard of the premises on the level of transaction prices, amounting to approximately 35\%. Most premises are located in tenement houses of medium technical condition, which is why the selection was made first, 
eliminating cases concerning real estate located in buildings after general renovations and in buildings with poor technical condition. There is no possibility of a reliable assessment of the standard of the flat, apart from the little data contained in the notarial deeds, hence one criterion has been adopted which is the technical condition of the building. At a later stage, premises located in close proximity to Aleja Trzech Wieszczy were separated from the base, so that the location criterion did not have a significant impact on the volatility of transaction prices. There was no significant share of the attribute which is the location on the story.

\section{Analysis of the significance of noise impact on the prices of residential properties}

The aim of the conducted research is to analyse the prices of separate apartments in terms of the impact of the environmental factor which is road noise. Property identification data and sales prices used in the analysis come exclusively from purchase contracts - sale of real estate. The property price and value register was not used, due to the incomplete range of information about the premises.

The work also uses the acoustic map of Krakow, which is one of the instruments for managing the acoustic climate. The distribution of noise level in the analysed area - the Ldwn indicator (day - evening - night) is presented in the form of Fig.1.

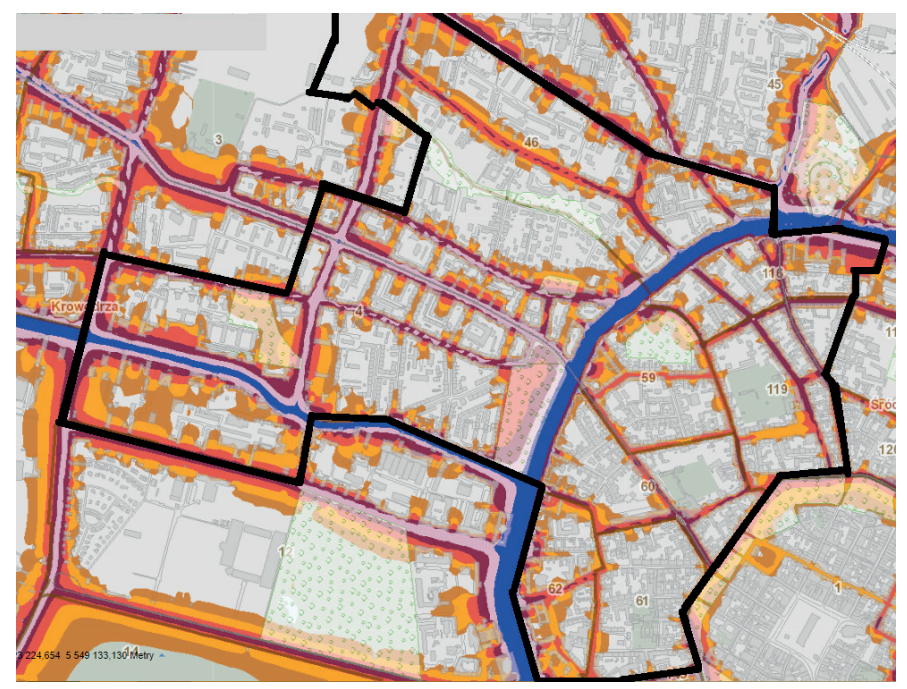

Fig. 1. The map of noise in the analysed area

The data collected concern dwellings located on the eastern and western side of Aleja Trzech Wieszczy, in the area including the cadastral districts of Krowodrza and Śródmieście, located closest to the main road route of the city with a noise level exceeding $75 \mathrm{~dB}$ during the day.

First of all, the entire base of residential premises, characterized by such attributes as:

- location - for which the scale was assigned in terms of distance from the Main Market Square in Kraków and perception of the attractiveness of the location of potential buyers in a given place,

- noise level - determined based on data from the acoustic map of Krakow, 
- usable floor space,

- technical condition of the building - determined based on data from notarial deeds and information obtained in the field.

Considering that the technical condition differentiates transaction prices at the level of about $35 \%$, first the selection of premises was made, leaving in the database those that are located in tenement houses of medium technical condition. Such a choice results from a much smaller number of buildings in poor and very poor technical condition as well as tenement houses that are renovated.

In this way, a collection of 76 premises was obtained, for which a histogram of unit transaction prices was presented below (Fig. 2).

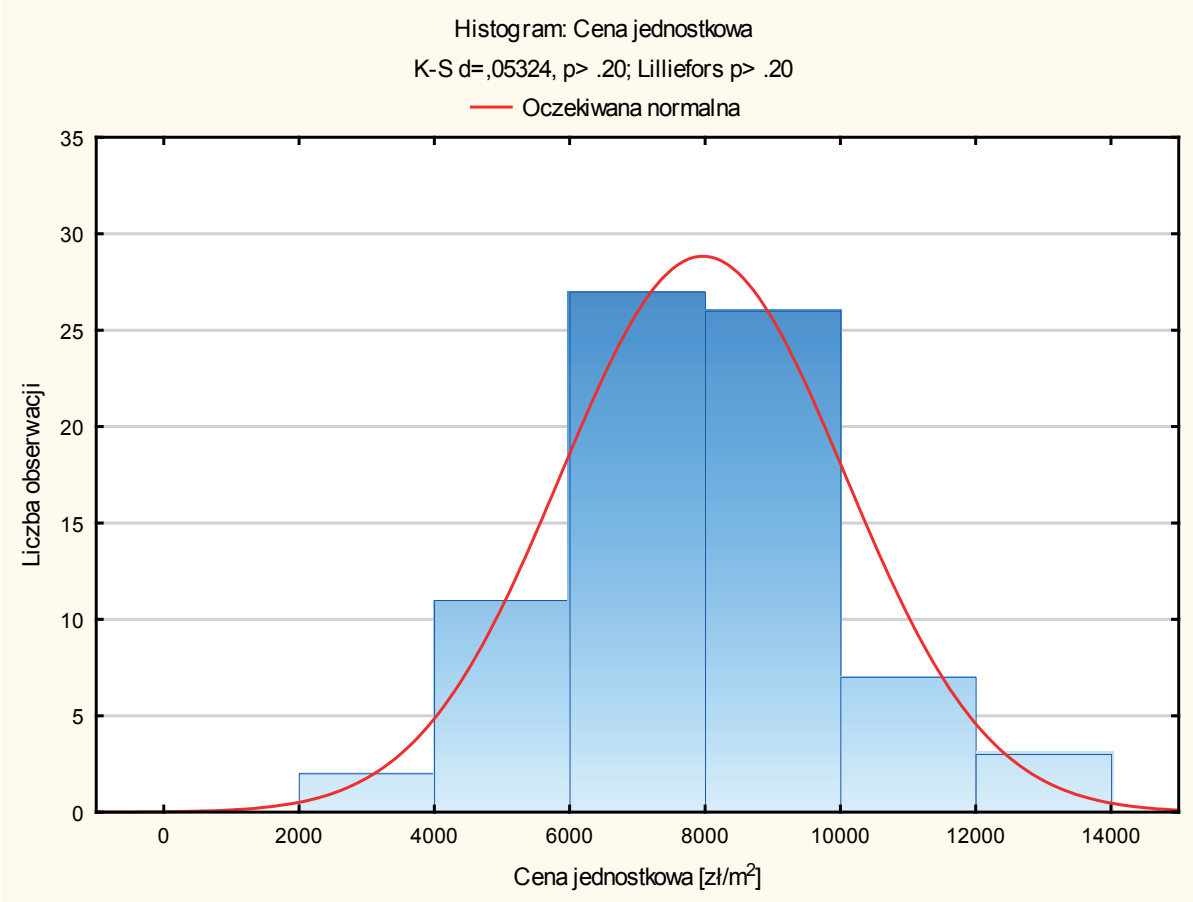

Fig. 2. Histogram of unit proces of residential premises

The basic characteristics of the dependent variable, i.e. the unit price in individual classes of noise level read from the acoustic map, are as follows:

Table 3. Table of number of residential premises in each noise classes

\begin{tabular}{llll}
\hline Noise compartment & Number of observation & $\begin{array}{l}\text { Average unit price } \\
{\left[\mathrm{z} / \mathrm{m}^{2}\right]}\end{array}$ & $\begin{array}{l}\text { Standard deviation of the unit price } \\
{\left[\mathrm{z} / \mathrm{m}^{2}\right]}\end{array}$ \\
\hline $50-55$ & 6 & 7694,876 & 1309,962 \\
\hline $55-60$ & 10 & 8068,003 & 2587,981 \\
\hline $60-65$ & 25 & 8296,768 & 1665,206 \\
\hline $65-70$ & 21 & 7820,171 & 2536,704 \\
\hline $70-75$ & 14 & 7652,479 & 2191,174 \\
\hline
\end{tabular}


Considering the large price differentiation, which results from the impact of not only the noise level, but also other attributes of the property, in the next stage, properties were selected that are similar in terms of location and usable space. In this way, a database of 26 properties exposed to noise at a level of 55 to $75 \mathrm{~dB}$ was obtained. The significance of the noise impact on the unit price of residential premises was examined using a one-way analysis of ANOVA, where the grouping factors are 4 noise intervals.

The significance of differences between expected unit price values from individual noise groups is tested by comparing variance. The calculations indicate significant differences in average real estate prices caused by the impact of road traffic noise and the basis for rejecting the hypothesis about the equality of means at the level equal to $p=0.0121$, with the assumed level of significance $p=0.05$. It illustrates in a clear graphical illustration of the results of the analysis of variance.

Hałas; Oczekiwane średnie brzegowe

Bieżący efekt: $F(3,22)=4,5926, p=, 01213$

Dekompozycja efektynnych hipotez

Pionowe słupki oznaczają 0,95 przedziały ufności

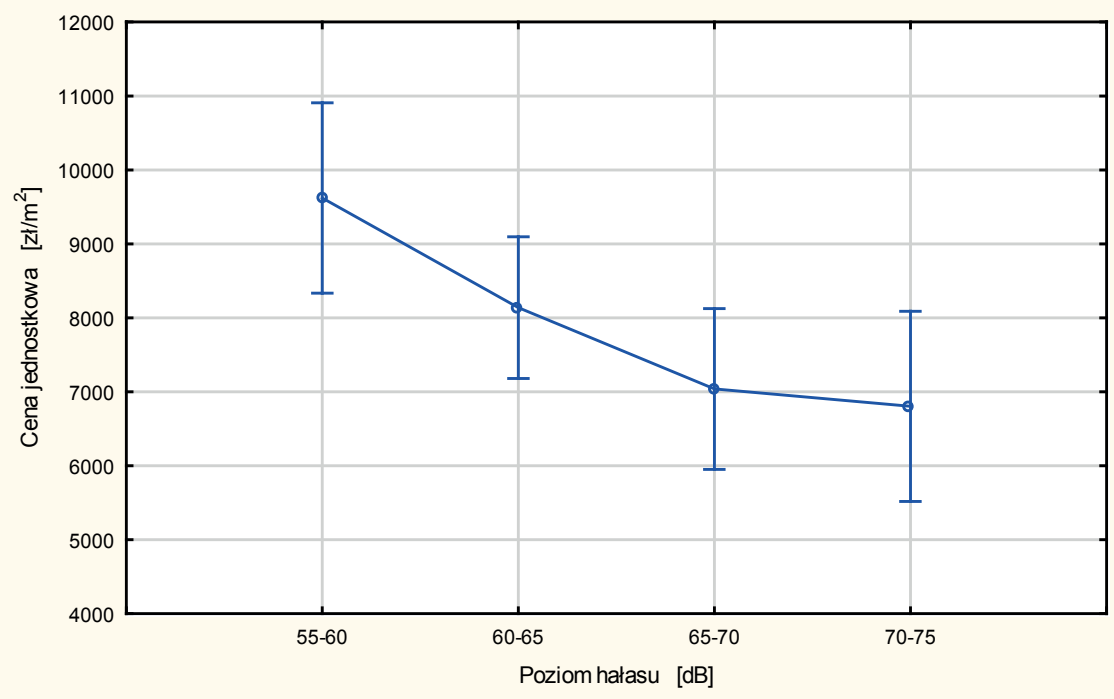

Fig. 3. Box chart for average procesprices in each proceprice classes

\section{Conclusion}

Performed real estate market analyses or estimation activities include the stage of testing the significance of individual market attributes in explaining price volatility. It is a complicated task, which results from the basic features of real estate, including its complexity and diversity. In Poland, too little attention is paid to the importance of environmental factors in real estate valuations, and a small percentage of the appraisal reports prepared includes such analyses.

The aim of the conducted research was to check whether the noise level significantly influences the obtained prices when selling residential premises. Separation of a group of premises comparable in terms of location, technical condition and usable area enabled to check the significance of differences in average unit prices of properties depending on the noise levels adopted. 
The results obtained using the one-way analysis of ANOVA variance indicate significant differences in the level of average real estate prices, depending on which group of noise levels they belong to. As a result, in relation to the local real estate market being researched, noise is a market feature that should be taken into account in research or in the preparation of appraisal reports, along with other most frequently considered market features of real estate.

\section{Acknowledgements}

This work was carried out within the statutory studies of the AGH University of Science and Technology, Faculty of Mining Surveying and Environmental Engineering, Department of Integrated Geodesy and Cartography

\section{References}

[1] Wacek, P., "Modeling the relationship between transport infrastructure and innovation in the context of economic development", Issues of science studies, no. 3 (2013), pp. 187-209.

[2] Ratajczak, M., "Infrastructure and economic growth and development", Journal of Law, Economics and Sociology, 3rd ed., Vol. 4 (2000) pp. 83-102.

[3] Ustawa z dnia 27 kwietnia 2001 r. Prawo ochrony środowiska, Warszawa, Poland, Dz.U. 2017, no. 519.

[4] Directive no. 2002/49/EC of 25 June 2002 of the European Parliament and of the Council relating to the assessment and management of environmental noise, Official Journal of the European Communities.

[5] Leśnikowska - Matusiak I., \& Wnuk, A., "Impact of traffic noise on the state of human acoustic environment", Car Transport: scientific quarterly of the Motor Transport Institute, vol.3, 2014, pp. 37-63.

[6] Bateman, I. J., Day, B.H., Lake, I., Lovett, A.,'”The effect of road traffic on residential property values: a literature review and hedonic pricing study", Report for Scottish Executive, University of East Anglia, Economic \& Social Research Council, 2001.

[7] Theebe, M. A. J., "Planes, trains and automobiles. The impact of traffic noise on house prices", Car Transport: scientific quarterly of the Motor Transport Institute, vol.3, 2002, pp. 37-63.

[8] Kucharska - Stasiak, E., Real estate in a market economy. Warszawa: Wydawnictwo Naukowe PWN, 2006

[9] Szopińska, K. and Krajewska, M., "Methods of Assessing Noise Nuisance of Real Estate Surroundings", Real Estate Management and Valuation, vol. 24, no. 1, 2016, pp. 19-30. https:// doi.org/10.1515/remav-2016-0002.

[10] Nelson, J. P., "Hedonic Property Value Studies of Transportation Noise: aircraft and road traffic" in Hedonic Methods in Housing Markets. Pricing Environmental Amenities and Segregation, (ed. Baranzini A. et al.), Springer, 2008, pp. 57-82.

[11] Cellmer, R. and Źróbek, S., "Applying GIS tools to studies over the impact of noise pollution on house prices", in The Future with GIS, Hrvatski Informatički Zbor - GIS Forum, Zagreb, 2011, pp. 245-256. https://doi.org/10.13140/RG.2.1.4887.0884

[12] Nelson, J. P., "Highway noise and property values. A survey of recent evidence", Journal of Transport Economics and Policy, vol. 16 (2), 1982, pp. 117-138.

[13] Rich, J. and Nielsen, O., “Assesment of Traffic Noise Impacts”, International Journal of Environmental Studies, Vol. 61, (2004).

[14] Bateman, I. J., Day, B.H. and Lake, I., "The valuation of transport - related noise in Birmingham", Technical Report to the DfT, Centre for social and economic research on the global environment and Centre of environmental risk, School of environmental Sciences, University of East Anglia, UK, 2004. 
[15] Thematic studies. Noise hazard. Selected Issues. Warszawa, Poland, Chancellery of the Senate. Analysis and Documentation Office, 2012.

[16] Rozporządzenie Ministra Środowiska z dnia 14 czerwca 2007 r. w sprawie dopuszczalnych poziomów hałasu w środowisku, Dz.U. 2014 no. 112.

[17] Gnat, S. and Bas, M., "Badanie wpływu imisji hałasu komunikacyjnego na ceny lokali mieszkalnych" in Scientific Monograph Market analysis and property management. Towarzystwo Naukowe Nieruchomości, 2014, pp. 73-86.

[18] Wilhelmsson, M. "The impact of traffic noise on the values of the single-family houses", Journal of Environmental Planning and Management, vol. 43, 2000, pp. 799-815. 
